УДК 336.71

DOI: https://doi.org/10.26642/jen-2019-4(90)-230-235

В.В. Романів, студ.

Н.О. Дорошенко, к.е.н., доц.

Харківський начіональний університет ім. В.Н. Каразіна

\title{
Фінансова безпека України
}

Питання забезпечення фінансової безпеки та ї̈ складових у будь-якій краӥні є надзвичайно актуальними. Це зумовлено тим, щцо сучасні вимоги щцодо створення сталого розвитку економіки краӥни потребують неабияких глобальних дій держави, щь пов'язані з широким колом питань реформування, які неможливі без забезпечення фінансової держави. Фінансова безпека має бути більш гнучкою та швидко функціонувати у відповідь на трансформації внутрішніх $i$ зовнішніх загроз. Адже неефективна фінансова безпека супроводжується дестабілізацією державних фінансів, щзо може призвести до виведення капіталів за кордон, девальвачії національної валюти, кризи платіжного балансу, зростання бюджетного дефіциту та державного боргу. Економіка будь-якої краӥни в прочесі свого розвитку зазнає значних змін, що пов 'язані з такими факторами, як: політичні, технічні та технологічні, суспільні явища.

У сучасних умовах економічного розвитку забезпечення фінансової безпеки краӥни є однією з важливих складових ї̈ фінансової політики. Для крайн, щьо мають не досить стійкі системи державних фінансів, цее питання є особливо актуальним. Передусім це стосується Украӥни. У статті розглянуто проблеми фінансової безпеки Украйни. Вирішення циих проблем повинно базуватися на надійній та ефективній системі захисту національних інтересів держави. Під фінансовою безпекою слід розуміти захист національних інтересів фінансово-кредитної сфери від впливу внутрішніх $і$ зовнішніх загроз.

Ключові слова: фінансова безпека; складові фінансової безпеки; індикатор; стабільність; Україна.

Актуальність теми. Сфера безпеки є актуальним предметом досліджень з боку науковців, фахівців 3 економіки та фінансів, державних управлінців, політологів, соціологів тощо. Інтерес до безпеки у наукових дослідженнях $є$ відносно новим напрямком і зумовлений актуалізацією проблематики збереження і розвитку особистості, громадянина, суспільства, держави, нації і цивілізації в цілому.

Саме слово «безпека» походить від грецького «володіти ситуацією». Фінансова безпека є важливою складовою економічної безпеки країни, яка визначається як спроможність держави самостійно виробляти й здійснювати власну економічну політику, а також визначати та реалізувати власні національні інтереси [1, с. 376].

Аналіз останніх досліджень та публікацій. Проблема фінансової безпеки є досить поширеною та розглядається в багатьох роботах, що присвячені економічній безпеці. Значний внесок у розвиток сучасної теорії безпекознавства зробили О.Барановський, М.Срмошенко, Н.Кравчук, В.Ліпкан, В.Мартинюк, В.Предборський, А.Сухоруков та ін. Проводили вагомі дослідження та привносили свої розробки в теорію з цього питання такі зарубіжні вчені, як: Дж.-К. Ван Хорн, К.Жюгляр, Дж.Найт, Т.Аліссон, Г.Фостер, Й.Шумпетер. В їх працях детально проаналізовано історичні, теоретичні та практичні аспекти фінансової безпеки держави.

Мета статті. Метою написання даної роботи є розкриття сутності фінансової безпеки держави, визначення особливостей ії сучасного стану в Україні та шляхів забезпечення, що дозволить розробити більш ефективну систему забезпечення фінансової безпеки країни у подальшому.

Викладення основного матеріалу. Критерій економічної безпеки - це оцінка стану економіки 3 погляду найважливіших процесів, що відображають сутність економічної та фінансової безпеки. 3 огляду на це, критеріальна оцінка безпеки містить у собі оцінки:

ресурсного потенціалу та можливостей його розвитку;

рівня ефективності використання ресурсів, капіталу і праці та його відповідності рівневі в розвинутих країнах, а також рівневі, за якого загрози внутрішнього і зовнішнього характеру зводяться до мінімуму; конкурентоздатності економіки;

цілісності території та економічного простору.

Фінансова безпека будь-якої держави являє собою цілісне поняття, що містить різноманітні елементи. Так складовими фінансової безпеки України є: бюджетна безпека, податкова безпека, боргова безпека, фінансова безпека банківської системи, валютна безпека, грошово-кредитна безпека, інвестиційна безпека, фінансова безпека страхового та фондового ринку.

(C) В.В. Романів, Н.О. Дорошенко, 2019 
Основна мета фінансової безпеки держави - ефективне використання державних ресурсів для запобігання фінансовим загрозам і забезпечення сталого розвитку й функціонування економіки в майбутньому [1].

Фінансова безпека - це такий стан фінансової сфери держави, для якої характерними є ефективність та збалансованість, гарантія стійкості фінансової системи до впливу внутрішніх і зовнішніх негативних чинників, а також уможливлення стабільного економічного зростання та синергетичний розвиток країни.

Фінансова безпека складається 3 монетарного, бюджетного, валютного, інвестиційного, інфляційного, цінового та боргового аспектів. Вона розглядається як у внутрішньому, так і зовнішньому ракурсах. У внутрішньому плані показниками стану фінансової безпеки $\epsilon$ характер формування державного та місцевих бюджетів, стан платіжного балансу країни, співвідношення грошових мас в офіційній і тіньовій економіках, ступінь ліквідності грошових коштів. Зовнішня фінансова безпека значною мірою визначається ступенем фінансової незалежності держави, обсягами іноземних інвестицій, міжнародним боргом країни, рівнем політичної стабільності [2, с. 94].

Наявність системи фінансової безпеки має передбачати методологію щодо оцінки ступеня впливу загроз на фінанси країни, тобто ефективності системи. Ступінь впливу загроз визначається на підставі розрахунку і моніторингу ряду індикаторів та порівняння їх із граничними (нормативними) значеннями.

Індикатор - елемент, що відображає процес або стан об'єкта спостережень, його якісні та кількісні характеристики. Говорячи про вибір індикатора, необхідно зазначити, що кожен показник має бути економічною величиною, яка має чіткі межі коливань. Слід розрізняти індикатори міжнародного рівня та національного відстеження та впливу [3].

Рівень фінансової безпеки країни оцінюють за індикаторами, що наведені в таблиці 1.

Нинішня економічна ситуація в Україні переконливо свідчить про те, що проблема забезпечення фінансової безпеки набуває першочергового значення і актуальності. Проаналізувавши всі складові фінансової безпеки України, ми визначили найпоширеніші проблеми щодо її забезпечення (табл. 1).

Таблиияя 1

Головні проблеми складових фінансової безпеки в Україні

\begin{tabular}{|c|c|}
\hline $\begin{array}{c}\text { Складові } \\
\text { фінансової безпеки }\end{array}$ & Проблеми \\
\hline Бюджетна безпека & $\begin{array}{llll}\bullet & \text { Прорахунки в бюджетному плануванні. } & \\
\bullet & \text { Надмірний рівень дефіциту державного бюджету та } \\
\text { недостатнє і несвоєчасне наповнення джерел його покриття } & \text { та }\end{array}$ \\
\hline Боргова безпека & $\begin{array}{l}\text { • Недосконалість нормативно-правової бази формування, } \\
\text { використання, обслуговування й погашення державного боргу } \\
\text { України. } \\
\qquad \quad \text { Відсутність чіткої обгрунтованої концепції управління } \\
\text { державним боргом }\end{array}$ \\
\hline Грошово-кредитна безпека & Втеча капіталу за кордон \\
\hline Валютна безпека & • $\quad$ Високий ступінь доларизації вітчизняної економіки \\
\hline Інвестиційна безпека & $\begin{array}{l}\text { • Недостатня мотивація до інвестиційної діяльності різних } \\
\text { груп економічних агентів. } \\
\text { • Збереження високих інвестиційних ризиків. } \\
\text { • Відсутність ефективних } \quad \text { механізмів } \\
\text { заощаджень населення в інвестиції }\end{array}$ \\
\hline Банківська безпека & $\begin{array}{l}\text { • Недостатня ліквідність банківських активів. } \\
\text { • Відсутність достатнього золотовалютного запасу. } \\
\text { • Відсутність довіри населення і юридичних осіб до } \\
\text { комерційних банків }\end{array}$ \\
\hline $\begin{array}{c}\text { Безпека небанківського } \\
\text { фінансового сектору }\end{array}$ & $\begin{array}{l}\text { • Слабкий розвиток інфраструктури страхового ринку. } \\
\bullet \quad \text { Недосконалість нормативно-правового забезпечення щодо } \\
\text { цінних паперів, обліку прав їхніх власників та корпоративного } \\
\text { управління. } \\
\qquad \quad \text { Вузький асортимент страхових послуг }\end{array}$ \\
\hline
\end{tabular}

На фінансову безпеку будь-якої країни безпосередньо впливають як внутрішні, так і зовнішні фактори економічного середовища, до яких можна зарахувати динаміку іноземних (прямих та 
портфельних) інвестицій, стан платіжного балансу, параметри валютного курсу, розвиток міжнародного кредиту, рівень монетизації ВВП, динаміку державного боргу тощо.

Фактори, що впливають на фінансову безпеку держави, можна поділити на такі, що прямо вживають і опосередковано влив. В свою чергу, фактори прямого впливу поділяються на негативні та позитивні.

Для аналізу стану фінансової безпеки України дамо оцінку основним фінансовим індикаторам. Спершу потрібно розглянути грошові агрегати та індекс споживчих цін. Динаміка зростання грошової маси показана на рисунку1

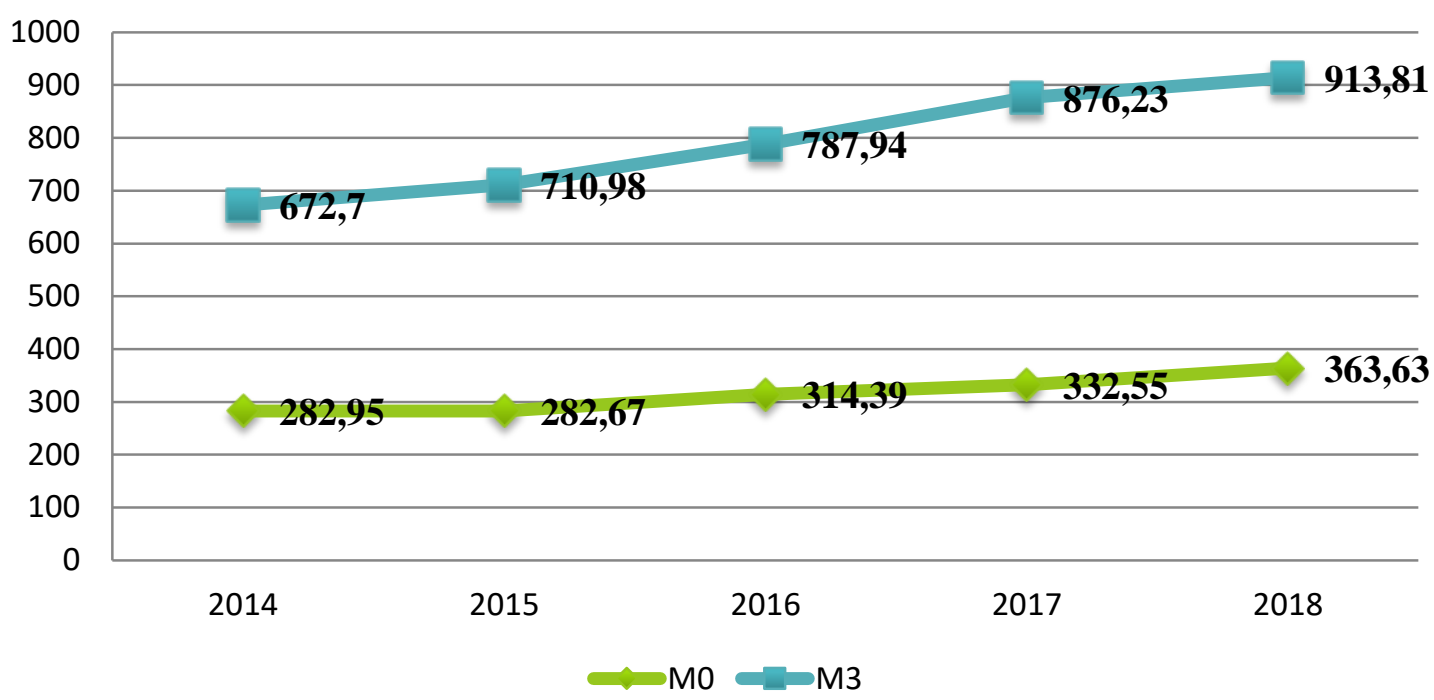

Рис. 1. Зростання грошової маси (агрегати М0 і М3) в Украӥні (2014-2018 роки, млрд грн) [5]

Можемо констатувати стабільне зростання грошової маси до 2018 року включно, що говорить про емісію грошових коштів. Також, за даними Національного банку України на грудень 2018 року, така динаміка обумовлена зростанням залишку по депозитах на 4,3 \% - до 910,996 млрд грн, і обсягом готівкових коштів в обігу поза банками - на 3,8 \%, до 364,753 млрд грн.

Індекс споживчих цін, або індекс інфляції в Україні впродовж всієї історії незалежності держави характеризується значними темпами коливання. (рис. 2).

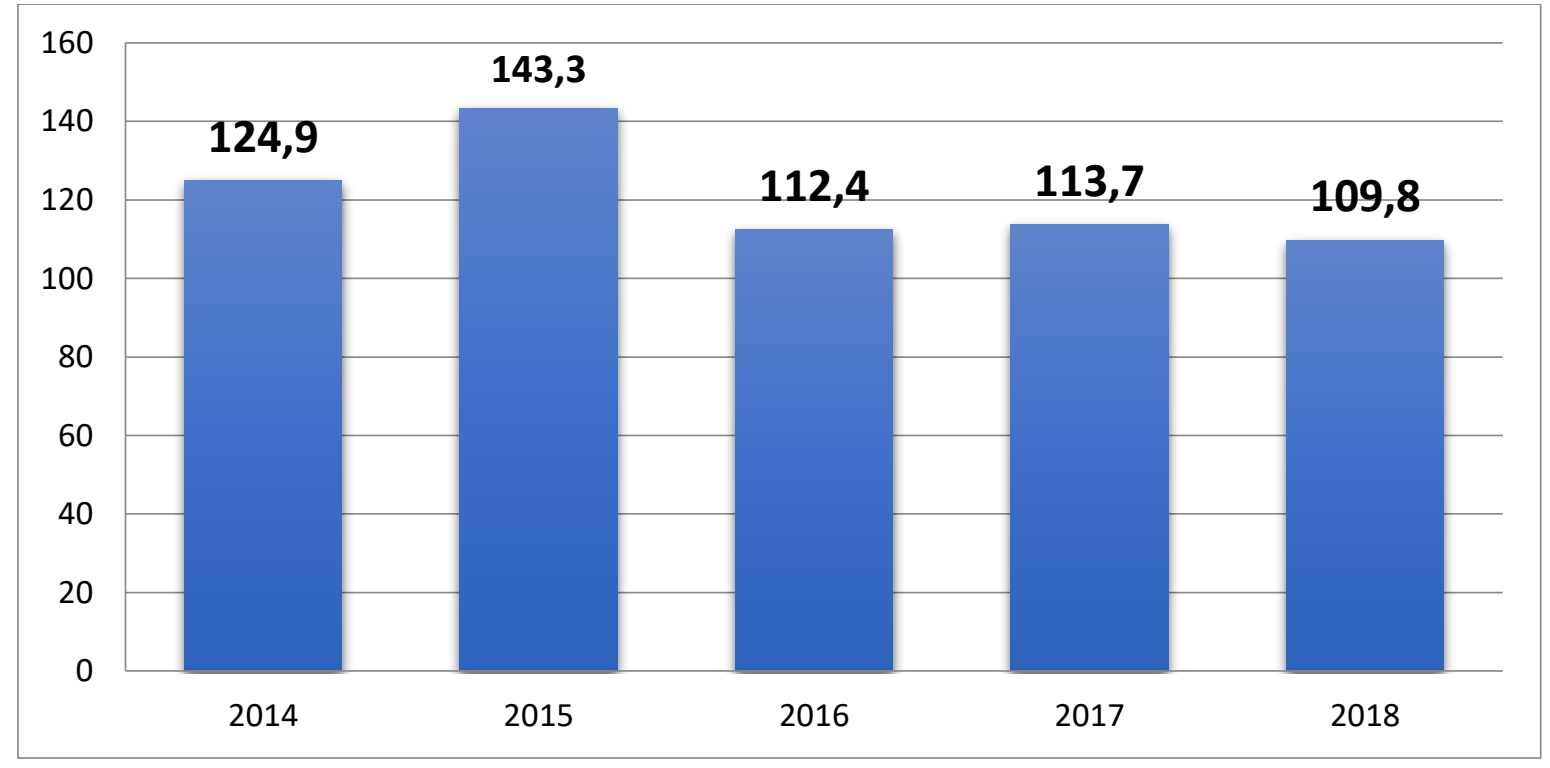

Рис. 2. Індекс інфляиії в Україну 2014-2018 роках [6] 
Внаслідок зростання грошової маси, тобто випуску в обіг грошових коштів, що підтверджено на рисунку 2, відповідно зростають і споживчі ціни в країні до 2015 року включно. 32016 року темп інфляції зменшився, а з 2018 - інфляція повернулася до помірного рівня. Не можна назвати наявний індекс інфляції стабілізуючим, але в умовах економіки, що розвивається, помірний темп інфляції $є$ допустимим, і навіть стимулюючим фактором для економіки.

Далі розглянемо динаміку валового внутрішнього продукту України (рис. 3). Необхідно зазначити, що ВВП України має тенденцію до збільшення. 32014 року ВВП країни зростає досить значними темпами, та за прогнозами НБУ динаміка і надалі залишиться позитивною.

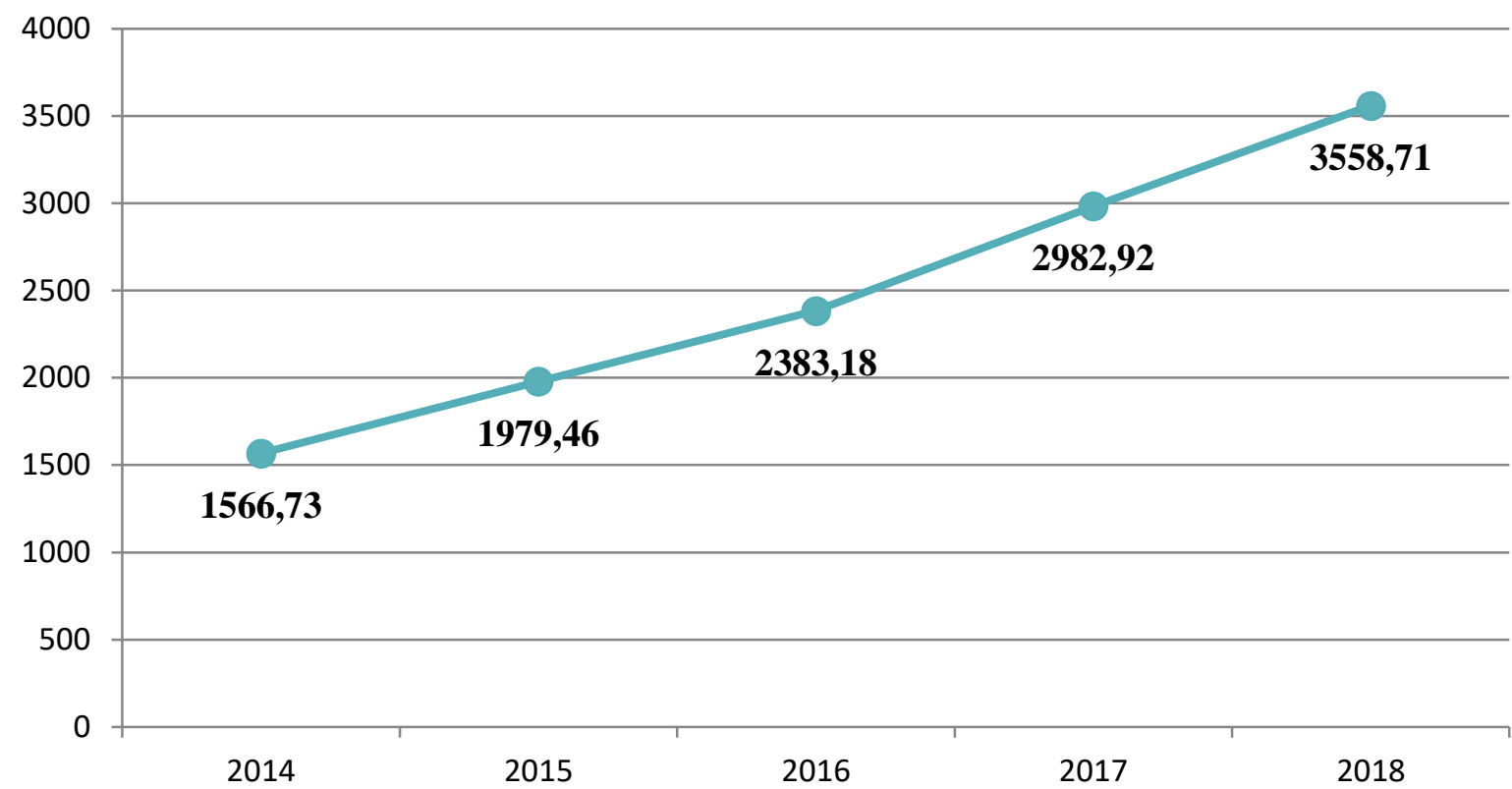

Рис. 3. Динаміка валового внутрішнього продукту України за період 2014-2018 років(млрд грн) [6]

Продовження зростання валового внутрішнього продукту та інші позитивні зміни, що сталися в українській економіці за останні роки, формують доволі хороші передумови подальшого розвитку економіки у найближчому майбутньому.

Міністерством економіки України розроблено методику розрахунку рівня економічної безпеки, в якій виокремлено групу індикаторів фінансової безпеки: бюджетна безпека, безпека грошового ринку та інфляційних процесів, валютна безпека, валові міжнародні резерви, безпека страхового ринку, безпека фондового ринку, банківська безпека. Ступінь впливу загроз можна визначити на основі моніторингу системи показників та порівняння їх із пороговими значеннями (табл. 2).

Таблиия 2

Динаміка показників фінансової безпеки за методикою Національного інституту проблем міжнародної безпеки України за 2014-2018 р.

\begin{tabular}{|c|c|c|c|c|c|c|c|c|}
\hline \multirow[b]{2}{*}{ Індикатор } & \multirow{2}{*}{$\begin{array}{l}\text { Порогове } \\
\text { значення }\end{array}$} & \multicolumn{5}{|c|}{ Рік } & \multicolumn{2}{|c|}{ Абсол. відх. (+/-) } \\
\hline & & 2014 & 2015 & 2016 & 2017 & 2018 & $\begin{array}{l}2016 \text { р. від } \\
2014 \text { р. }\end{array}$ & $\begin{array}{l}2018 \text { р. від } \\
2016 \text { р. }\end{array}$ \\
\hline Рівень інфляції, \% & 5 & 24,9 & 43,3 & 12,4 & 13,7 & 9,8 & $-12,5$ & $-3,9$ \\
\hline $\begin{array}{c}\text { Обсяг внутрішнього } \\
\text { боргу, \% ВВП }\end{array}$ & $\begin{array}{c}\text { Менше } \\
30 \% \text { ВВП }\end{array}$ & 70,26 & 79,4 & 81,0 & 71,8 & 60,9 & 10,74 & $-20,1$ \\
\hline $\begin{array}{l}\text { Обсяг зовнішнього } \\
\text { боргу, \% ВВП }\end{array}$ & $\begin{array}{l}\text { Менше за } \\
20 \% \text { ВВП }\end{array}$ & 95,8 & 131,0 & 121,7 & 103,9 & 87,9 & 25,9 & $-33,8$ \\
\hline $\begin{array}{c}\text { Дефіцит державного } \\
\text { бюджету, \% ВВП }\end{array}$ & $1 \%$ ВВП & 4,98 & 2,28 & 2,94 & 1,60 & 1,66 & $-2,04$ & $-1,28$ \\
\hline $\begin{array}{c}\text { Вартість } \\
\text { банківських } \\
\text { кредитів, річних, \% }\end{array}$ & $\begin{array}{c}\text { Не більше } \\
\text { за } 10 \% \\
\text { річних } \\
\end{array}$ & 26,1 & 29,5 & 18,3 & 15,1 & 18,8 & $-7,8$ & 0,5 \\
\hline $\begin{array}{l}\text { Міжнародні резерви } \\
\text { (без золотих), млрд } \\
\text { дол. США }\end{array}$ & $\begin{array}{l}\text { До } 5 \text { млрд } \\
\text { дол. США }\end{array}$ & 6,62 & 12,37 & 14,59 & 17,48 & 18,05 & 7,97 & 3,46 \\
\hline
\end{tabular}


Значення усіх показників протягом 2014-2018 років суттєво перевищують порогові значення. Так рівень інфляції був найвищим у 2015 році (майже у десять разів перевищив встановлене порогове значення), а найнижчим у 2018 році $-9,8 \%$.

Висновки та перспективи подальших досліджень. Для поліпшення стану фінансової безпеки держави, перш за все, необхідно виявити існуючі проблеми. Їх слід розділити на внутрішні та зовнішні, а кожні з них розглядати не лише зі сторони фінансової безпеки, але й зі сторони економічної 3 метою отримання повної інформації щодо них.

Так внутрішніми загрозами у сфері економічної безпеки є:

1) розширення межі майнового розшарування суспільства;

2) криміналізація економіки і суспільства;

3) зниження науково-технічного потенціалу країни;

4) зниження інвестиційної привабливості;

5) ослаблення інвестиційно-інноваційного іміджу;

6) слабкість інноваційного початку розвитку підприємницької діяльності;

7) низька конкурентоспроможність і тотальне згортання виробництва;

8) різка відмінність у рівні соціально-економічного розвитку регіонів, що руйнує існуючі зв'язки між ними і перешкоджає міжрегіональній інтеграції [8].

Внутрішні загрози пов'язані з недолугою фінансово-економічною політикою, прорахунками, зловживаннями та іншими відхиленнями зі сторони органів влади в управлінні фінансовою системою держави.

Внутрішні проблеми можуть бути ефективно вирішені лише внаслідок розв'язання зовнішніх загроз.

Зовнішніми загрозами в сфері економічної безпеки є:

1) відтік умів за кордон;

2) нелегальний вивіз капіталу за кордон;

3) наростання імпортної залежності з продовольства і споживчих товарів;

4) недобросовісна конкуренція;

5) відсутність законів, що дозволяють в повному обсязі протидіяти недобросовісній конкуренції;

6) знецінення національної валюти;

7) зниження зовнішньої інвестиційної привабливості;

8) відсутність економічного і політичного впливу на процеси, які відбуваються у світовій економіці;

9) ослаблення процесів інтеграції та налагодження економічних зв'язків України з країнами СНД;

10) слабка інформаційна база;

11) зростання зовнішнього боргу [9].

Усі ці проблеми потребують термінового вирішення шляхом запровадження високоефективних реформ.

Виявивши існуючі проблеми у сфері забезпечення фінансової безпеки, слід обрати пріоритетні напрями її зміцнення.

До таких напрямів варто зарахувати, перш за все, реформування бюджетної системи шляхом проведення бюджетних реформ на базі наукового обгрунтування та координації дій (розробки узгоджених концепцій), стратегії та тактики бюджетування, підвищення якості прогнозів макроекономічних показників, що використовуються в бюджетному плануванні. У даному напрямі пропонується здійснити такі зміни:

1) зменшити зовнішній борг України шляхом прямого зменшення чистих зовнішніх залучень уряду та погашення довгострокових залучень реального сектору економіки;

2) удосконалити систему бюджетної статистики та діагностики у системному аналізі з індикаторами грошово-кредитної, боргової та валютної безпеки;

3) розробити поетапну стратегію скорочення бюджетного дефіциту за рахунок нарощення власного доходного потенціалу, підвищення рівня управління державним боргом шляхом реалізації сучасної стратегії залучення позичкового капіталу, інвентаризації та класифікації всіх боргів, трансформації структури боргу, недопущенні практики прийняття виключних рішень, непідпорядкованих єдиній борговій політиці, ліквідації прихованого дефіциту.

На останок необхідно реформувати регулювання страхового ринку через сприяння розвитку страхового ринку та удосконалення порядку ліцензування діяльності страховиків, дотримання вимог до джерел формування статутного капіталу та фінансового становища засновників. Також слід:

1) створити фонд гарантування страхових виплат за договорами страхування;

2) ввести міжнародні норми корпоративного управління для страховиків та розробити державну цільову програму науково-дослідних робіт у сфері страхування та підготовки фахівців для страхового ринку;

3) удосконалити систему оподаткування страховиків та операцій перестрахування у перестраховиківнерезидентів.

Реалізація запропонованого комплексу заходів, що охоплює більшість складових фінансової безпеки, актуальних для України, дозволить значно підвищити іiі рівень за умови забезпечення підтримки на законодавчому, виконавчому, владному рівнях [9]. 
Як висновок, можна сказати, що, на жаль, фінансова безпека України ще знаходиться на низькому рівні розвитку. Тому сьогодні як ніколи загострюється надзвичайно важливе питання забезпечення фінансової безпеки України, що є одним 3 найважливіших національних пріоритетів і вимагає посиленої уваги представників владних структур, громадських і політичних рухів, науковців, широких кіл громадськості.

Забезпечення фінансової безпеки є гарантом державної незалежності України, умовою ії сталого розвитку та зростання добробуту громадян. Проте забезпечення економічної та фінансової безпеки України неможливе без завершення структурної перебудови національної економіки і підвищення пї конкурентоспроможності.

\section{Список використаної літератури:}

1. Глущенко В.В. Економічна безпека фінансових установ : монографія / В.В. Глущенко, Г.О. Дорошенко, Н.О. Дорошенко. - Х. : Щедра садиба плюс, 2014. - 232 с.

2. Радзівіл K. Поняття та зміст фінансової безпеки держави / К.Радзівіл // Підприємництво, господарство і право. - 2011. - Вип. 5. - С. 94-97.

3. Царук O.B. Концептуальні основи та статичні індикатори оцінки боргової безпеки держави / О.В. Царук // Світ фінансів. - 2012. - № 1 (10). - С. 46-50.

4. Фінансова безпека держави [Електронний ресурс]. - Режим доступу : https://pidruchniki.com/15931106/finansi/finansova_bezpeka_derzhavi.

5. Офіційний сайт Національного банку України / Національний банк України [Електронний ресурс]. - Режим доступу : https://bank.gov.ua.

6. Офіційний сайт Державної служби статистики України / Державна служба статистики України [Електронний ресурс]. - Режим доступу : http://ukrstat.gov.ua.

7. Офіційний сайт Державної казначейської служби України / Державна казначейська служба України [Електронний ресурс]. - Режим доступу : http://www.treasury.gov.ua.

8. Фінансова безпека України [Електронний ресурс]. - Режим доступу : https://www.kazedu.kz/referat/201552/6.

9. Луцик-Дубова Т.О. Основні пріоритети зміцнення фінансової безпеки України / Т.О. Луцик-Дубова // Наукові праці Кіровоградського національного технічного університету. Серія : Економічні науки. - 2012. Вип. 22, Ч. II. - С. 1-6.

\section{References:}

1. Glushhenko, V.V., Doroshenko, G.O. and Doroshenko, N.O. (2014), Ekonomichna bezpeka finansovyh ustanov, monografija, Shhedra sadyba pljus, Harkiv, 232 p.

2. Radzivil, K. (2011), «Ponjattja ta zmist finansovoi' bezpeky derzhavy», Pidpryjemnyctvo, gospodarstvo i pravo, Vol. 5, pp. 94-97.

3. Caruk, O.V. (2012), «Konceptual'ni osnovy ta statychni indykatory ocinky borgovoi' bezpeky derzhavy», Svit finansiv, No. 1 (10), pp. 46-50.

4. «Finansova bezpeka derzhavy», [Online], available at: https://pidruchniki.com/15931106/finansi/finansova_bezpek a_derzhavi

5. Nacional'nyj bank Ukrai'ny, «Oficijnyj sajt Nacional'nogo banku Ukrai'ny», [Online], available at: https://bank.gov.ua

6. Derzhavna sluzhba statystyky Ukrai'ny, «Oficijnyj sajt Derzhavnoi' sluzhby statystyky Ukrai'ny», [Online], available at: http://ukrstat.gov.ua

7. Derzhavna kaznachejs'ka sluzhba Ukrai'ny, «Oficijnyj sajt Derzhavnoi' kaznachejs'koi' sluzhby Ukrai'ny», [Online], available at: http://www.treasury.gov.ua

8. Finansova bezpeka Ukrai'ny (2015), [Online], available at: https://www.kazedu.kz/referat/201552/6

9. Lucyk-Dubova, T.O. (2012), «Osnovni priorytety zmicnennja finansovoi' bezpeky Ukrai'ny», Naukovi praci Kirovograds'kogo nacional'nogo tehnichnogo universytetu, Serija Ekonomichni nauky, Vol. 22, Part II, pp. 1-6.

Романів Вікторія Віталіївна - студентка Харківського Національного університеу ім. В.Н. Каразіна. Наукові інтереси:

- фінанси;

- банківська система;

- фінансова грамотність;

- фінансова безпека.

Дорошенко Надія Олександрівна - кандидат економічних наук, доцент Харківського національного університету ім. В.Н. Каразіна.

Наукові інтереси:

- фінанси;

- банківська справа;

- кредитні ризики;

- інвестування;

- фінансова безпека. 